\title{
Non-Participative Political Culture in Hungary - Why are the Particpatory Pillars of Democratic Political Culture Weak in Hungary?
}

\author{
János SIMON \\ Kodolányi János Főiskola, Székesfehérvár, Budapest \\ Nemzetközi Tanulmányok és Történelem Intézeti Tanszék \\ Kodolányi János University of Applied Sciences, Székesfehérvár, Budapest \\ Department of International Studies and History \\ Fürdő u. 1, 8000 Székesfehérvár, Hungary \\ Rendszerváltás Történetét Kutató Intézet és Archívum \\ Research Institute and Archives for History and System Change \\ Kossuth tér 1-3, 1055 Budapest, Hungary \\ janossimon11@gmail.com
}

\section{Theory of political and civic culture}

We are approaching 2014 - the year of elections, which, with the development of democracy in Hungary forces us to analyze the question why there is such a low level of willingness to participate in our electoral activity and in public life in general? What factors hinder and hamper a larger citizen participation based on the development of civil society as its pillars? In the following we are looking for answers to these questions by examining the character, political culture and behavior in the history and sociological, psychological, and political approach to the civil society.

The structure of the four decades of authoritarian system (1949-1989) was a "shattered structure", in behavior it left a legacy of a "defensive" civil society, two decades of democratic development was not enough for the reconstruction and activation in Hungary. In this study we are searching for the reasons. From 1990 to 2010, or in other words from the transition we can follow the development of the Hungarian political culture till the stabilization of pluralistic democracy, basically from the civil society's point of view. We examine the political culture of civil-society development of the communist regime, when they broke its structure and forced them to defend, then during the period of the system changes and the following two decades made it possible to build, to alter, the renaissance of civil society. We are going to look into the matters influencing the fate of the civil society organizations which were forming during the governments. We are also looking for the answer whether it started the regeneration, self-organization and renaissance of the civil society that once was atomized and forced to defend itslef, and that may lead towards building civil society participatory described by Almond and Verba authors. ${ }^{1}$

1 Gabriel A. ALMOND - Sidney VERBA, The Civic Culture. Political Attitudes and Democracy in Five Nations, Princeton 1963. 
The political culture is a subjective dimension of the policy, which expresses the citizen's relationship with the world of politics. ${ }^{2}$ One of the most succinct definitions of political culture comes from Samuel Beert who writes that "the components of the political culture are values and ways of relationship, which should govern the nation". ${ }^{3}$ The concept was created in the late 1950s, even its first users (Pye, Almond and Verba) have been approached in two ways: the behavior and the attitudes respectively. ${ }^{4}$ From the synthesis of the two concepts and scientific products since then I determine the following definition: "The political culture on the one hand consists of a historically established group-like attitudes, beliefs, judgments, emotions and symbols network, on the other hand it orients the political behavior and actions, and finally, ensures meaning and readability to the political processes." 5 The political culture is not constant, not something fixated, it changes over time and in the long run it responds to new challenges, and even these changes affect the new generations in different strengths. ${ }^{6}$

The term of civic culture was first used by the Almond-Verba authors in 1963 in their famous book "The Civic Culture". The civic culture was defined as the most advanced type of political culture which strengthens democracy. It separates the political activity and political passivity according to the political participation. Where the two more or less balance each other, where the public activity is specific, participation dominates and citizens actively influence the political life, then they think there is a modern "civic culture" which strengthens democracy. But where the passivity dominates, a traditional "subjected" civil society works with a "paternalistic" political culture. For example, when the signals of civil society are weak or the participation in the elections is low in the public life, then the political class will become more elite causing castes without control, doing whatever it wants, be it on the national or local government level. Thus, the activity and divisions between the active and passive forces and ratios are vital to civil society in strengthening the mass democracy. Our present study investigates this issue.

The largest charge against the behaviorist schools which are based on behavior of citizens is that their findings are limited because they are static, unhistorical, so either they are not taken into account, or they can not take into account the changes over time. ${ }^{7}$ To explain the way we have tried to bridge this problem, we need to mention our national surveys conducted by standardized questionnaires between 1989 and 2010. After gathering the data we created a Codebook, so in this way we could demonstrate the process of the

2 János SIMON, A politikai kultúra fogalma, in: A politikatudomány arcai, András A. GERGELY - József BAYER Kálmán KULCSÁR (eds.), Budapest 1999, 347-364.

3 Jacques RUPNIK, Politikai kultúra, in: Politikai kultúra és állam Magyarországon és Cseh-Szlovákiában, János GYURGYÁK - Gábor HALMAI (eds.), Torino, Budapest 1991, 11-17.

4 Lucien PYE, Political Culture, in: International Encyclopedia of the Social Science, Vol. 12, David L. SILLS (ed.), New York 1961, 218-224; ALMOND - VERBA.

5 János SIMON, The Main Pillars of Democratic Political Culture in Hungary, in: Central European Political Science Review, 13, 2012, 50, 12-13.

6 lbidem.

7 Philippe C. SCHMITTER, The Quality of Neo-Democracy in Central Europe, in: Central European Political Science Review, 3, 2002, 9, 25-42. 
transformation and we could create images about the direction and the nature of changes ${ }^{8}$. Two decades of research series, from which Codebooks were made, were accomplished by the author, which now offers a remarkable opportunity to analyze how the people had seen the political democratization and the process of privatization, and how big the impact of all these was on the evolution of their political culture. ${ }^{9}$ Should we answer the question of what the civil society is like and what kind of political culture has evolved over the past six decades in our country?

In our opinion, the balance of power between the political elite and civil society together means defining the character of the Hungarian democratization, the "pact-like" nature and the "quiet revolutionism" of it. Basically, the relationship of the political elite and civil society determined the nature and character of the transition. Old and new elite groups of political class played a major role in breaking down and building new institutions of democracy, in regulation and dictating the rules in monolithic political structure which was operating for four decades; however, the rhythm and the speed of transition were given by the civil society with its revival and strengthening. ${ }^{10}$

In the present study we will first examine how the fate of the civil society was forming over the particular governments and further which factors helped or hindered the strengthening of the key democratic system pillars on which the civic culture can be built. Could the Hungarian society be called civil cultural, or has it stuck on the level of subjected culture at all?

\section{The effect of the government on civil society (1949-2010)}

\section{II/1. The impact of two periods of dictatorship on civil society (1949-1989)}

The political culture of citizens can be described on the basis of the historical changes of the civil society. In the following, we will consider the activities of particular governments - the four decades of dictatorship and the two decades of democracy respectively (1948-2010) - in relation to the impact of the six decades of development on civil society. In 1949, the Soviets occupying our country forced a Stalin-like type of totalitarian communist constitution on the country, which remained in effect with minor modifications until the autumn of 1989. ${ }^{11}$ The expanding Rákosi regime from 1948 broke the structure of civil soci-

8 Ferge Zsuzsa for example, in 2012, in her book which is relies on older data (between 1995 and 2000), and she is complaining partly rightly about the lack of resources: "because of the lack of resources (which reflects the low esteem of the social sciences after all) unfortunately there is no continuation of our data. I wish it would ... ". (See Zsuzsa FERGE, Vágányok és vakvágányok a társadalompolitikában, Budapest 2012, 42). From this view Mary Kopp Skrabski Árpád's work is rare exception, and the time-series data collection related to lifestyle choices they have made [see Mária KOPP - Árpád SKRABSKI, Az életminőség dimenziói - a magyar népesség az ezredfordulón, Komárom 2007, URL: www.behsci.sote.hu/kopp-skrabsky-selye-centenarium-eloadas.htm (visited: February 2013).

9 János SIMON, A demokratikus politikai kultúra pillére Magyarországon - avagy közvélemény a magyar demokrácia 20 évéről. Codebook (hereinafter referred only as Codebook), Budapest-Józsefváros 2013, 121.

10 László BRUSZT - János SIMON, Lecsendesített többség, Budapest 1990; Mihály BIHARI - Béla POKOL, Politológia, Budapest 2009; János SIMON, Értékválság a politikában - A demokratikus politikai kultúra keresése, Budapest 2012, 190.

11 Zoltán LOMNICl, Why Did Hungary Need a to Adopt a New Constitution?, in: Central European Political Science Review, 12, 2012, 43, 49-58. 
ety with the act of banning the non-governmental organizations: foundations, associations, companies and circles. It suspended the democratic rights including freedom of assembly, freedom of speech and freedom of the press, and Rákosi kept the branch of powers under control in the center of the communist state party. From 1949, it was mandatory to attend the elections where the people could elect only the state party's men. Because of the effect of fear, according to the official results, $99 \%$ of the voters always went to the polls, and of those who voted $99.9 \%$ supported the nominee of the state's party on the parliamentary elections, and on the local elections which were on the same day. ${ }^{12}$

The two dictatorships - the Rákosi regime and the Kádár regime - both were consciously destroying the civil society, its existence was a challenge and a threat for them. Dictatorships did everything they could to eliminate the autonomy of civilians, to break their resistance, their activity and to defeat the atomized and subjected people. If we can find any difference between the two systems hallmarked with their politician's name, then it might be just the depth of destruction. In the second era of the dictatorship, in the Kádár era, the destruction was not as total and profound as in the Rákosi era which almost destroyed the civil organizations, fundamentally reduced their operations to a minimum, and banned or exterminated the thoughts of their leaders. ${ }^{13}$

The defeat of the 1956 revolution was followed by unprecedented terror which was mainly directed against the society active, critical and democratic forces. 56 had an important message to the leaders; in Hungary the democratic traditions had been so strong that with repression the country could not be permanently and effectively governed. However, the repression intimidated the civil society and, as a consequence, instead of the confrontational strategy of life the pursuit of "survival" strategies came into view. The latter atomized the society, people moved away from the public sector and caused retreat to the private sphere rather than strengthening the participation instead of absence. It seems to fit the term "defensive civil society" used by Polányi on the Hungarian civil society's attitude at the time of the one-party system. ${ }^{14}$ Kádár basically continued the same after 1956 , like his predecessor, first with coarse violence then with more sophisticated methods. Even in the 1970s and 1980s of goulash communism (called "consumer society") batons still swished, intimidation was strong, even though it did not receive as much publicity as before. The civilians, on the one hand, were intimidated by violence; on the other one, they were pacified with various promises; furthermore organized communities were smashed, the people became atomized and civil society organizations were banned. As a consequence, the civil society became both organizationally and as regards to its role "truncated", the intermediary value was little, and it was essentially left without representation, mostly it concentrated on the philatelist and small livestock farmers, and missed the entire process of regime change.

The elected multi-party parliament in 1990 added further elements to the "Temporary" Constitution, which was accepted in 1989, to guarantee democracy. The 1989-1990 re-

12 Csaba VARGA, On the Nature of Law in Communism, in: Central European Political Science Review, 12, 2011, 43, 19-48, URL: http://papers.ssrn.com/sol3/papers.cfm?abstract_id=2388420.

13 Máté SZABÓ, Dissent and Opposition in the Kadar-regime, in: Central European Political Science Review, 7, 2006, 26, 136-156.

14 Attila ÁGH, A civil társadalom kialakulása és fejlődése, Budapest 1989, 11-30. 
gime change was carried through with the negotiations of the Hungarian political class and with series of bargaining and agreement of elite groups, without public support. ${ }^{15}$

\section{II/2. The effect of political transition governments to civil society (1990-1998)}

It was clear even in 1988 and 1989 that the vast majority of the Hungarian society was not involved in the forming of political processes. People had been atomized, the vast majority stayed away from all areas of public life, such as local and national politics as well. It is enough to mention some of the reasons such as the 1950s communist terror, the reprisals after 1956, or the 60 years was filled with violence and torture and no wonder that the four-decade dictatorship terrific memories of retaliation burned in the memories of Hungarian families on almost a visceral level. ${ }^{16}$

From autumn 1988 the party germs, party formations and the subsequent political parties were forming successively. In the summer of 1989, selected representatives of the largest opposition parties excluded the public, sat in one of the rooms of the Parliament with the representatives of the four decades ruling state party (MSZMP) to discuss the distribution of power and progress. Negotiations behind closed doors between the old and new elites finally set out the date of the new elections. Narrowed by negotiations between elite groups the partners of "privileged parties" were selected. They were to develop the basic rules, electoral system, institutional framework, including the Provisional Constitution of democracy among themselves - without civil control. However, the political negotiation process managed to half-side because it omitted the people themselves.

In the "broken society", which lacked the organized civil force, as a result of the balance of power "broken system changes" had taken place. So in politics due to the continuity the old political forces were able to keep stronger positions than that of the forces of the change and renewal. Thus the democratic transition took place in the context of a special elite change, most of the party-state elite almost fled from power, because in return of the political power - through spontaneous privatization - as a power conversation the economic power was given to them. Many of them even in their new position supported the power and a few years later many of them have returned. Therefore, it was no their interests to mobilize hundreds of thousands of party members or the armed workers militia - that are still under their influence - to protect eroding political power. However, behind the just shaping opposition, only limited number of intellectual oppositions groups was standing, so the emerging new parties in the absence of awareness had virtually no public recognition of, and they lacked support of the masses behind them. The party-state elite as well as the opposition elite had the same interest - the unpredictable civil society off to agree with each other as soon as possible, thereby not only speed up the transition of

15 Samuel H. BARNES - János SIMON (eds.), Postcommunist Citizen, Budapest - Washington 1999 (2 ${ }^{\text {nd }}$ edition); Samuel H. BARNES - Max KAASE, Political Action: Mass Participation in Five Western Democracies, Beverly Hills 1979; Zoltán BERÉNYI, Behind the Facade: weak civic culture in Hungary, in: Central European Political Science Review, 7, 2006, 26, 112-136; Mihály BIHÁRI, Rendszerváltás és hatalomváltás Magyarországon 1989-1990, in: Magyarország politikai évkönyve, Sándor KURTÁN - Péter SÁNDOR - László VASS (eds.), Budapest 1991, 32-47; Imre POZSGAY, Politikuspálya a pártállamban és a rendszerváltásban, Budapest 1993.

16 BRUSZT - SIMON, 1990. 
power, but also retained its peaceful nature, which also means the social energy savings. ${ }^{17}$ The disadvantage is that the elites have become prone to be closed and sealed to form a political class that limits or prevents the pressure on, the transparency and the civil control of the decision-making politicians. All this worked against democratization, provided ample scope for corruption. ${ }^{18}$

The masses were kept quiet and left very uncertain: in case of a conflict which direction to move to, who to join? But why was the civil society left out? Specific loss of interest in the disorganization of civilians deepened the loss of large social compromise between civil society and the political class as well. No one asked the people during the transition to democracy what kind of democracy they wanted, what they thought of the new democratic system, the privatization of the interim Constitution, what they wanted, accepted, voted for. During the dictatorship the Hungarian civil society became a "paternalist"one - in Tocquevelle's words. The power made the civil society infantile with violence and socialization and forced it towards the paternalistic behavior, the essence of which was that people had to refrain from discussing the public affairs in favor of the ruling party participation. In return the state (government) was taking care of their social well-being. ${ }^{19}$ The interests are not represented, but the power included. People had no choice: either join the crowd or marginalize mentally and physically. This state paternalism lasted until the mid-1980s, when the state tried to transfer the burden from people's shoulders while the people maintained their strong demand for state paternalism, even long after the change of regime. In 1989, 51\% of respondents agreed with the statement that "it is better if you're not in politics, because sooner or later it comes off badly!". ${ }^{20} 62 \%$ of them felt that "as long as things are going well in the country, it does not really matter who is in power"; $64 \%$ of them agreed that "politicians are only happy if people do not intervene in their affairs". ${ }^{21}$

Within the Hungarian context, we can say that the transition did play a role in the political culture of the Hungarians, but in the sense that the weak civil society provided much more space to the political class (if you like the new political elite) than that in a democratic system construction would have been desirable. Specific transactions between the elite created more perverse side effects associated with it, which only became apparent later. One of these is that the agreement also guaranteed the old political elite that politicians responsible for crimes committed in the one-party system were prevented from the impeachment. This can be best explained on Prime Minister Jozsef Antall who claimed that "since the revolution did not like to do so, there would be no witch-persecutions!" But this statement was a double-edged sword, because it was not just the old elites who had to defend the spirit of continuity, but also it was to protect the new elite. If you like, it legally prepared the ground and the atmosphere to the new political elite who should be already

\section{POZSGAY.}

18 László MURAKÖZY (ed.), A bizalmatlanság hálójában. A magyar beteg, Budapest 2012; Mark BUCHANAN, Nexus - A hálózatok úttörő tudománya, Budapest 2013, 25-52; Pilar del CASTILLO - Ismael CRESPO (eds.), Cultura política. Enfoques teóricos y análisis, Valencia 1997; Mikolaj CZESNIK, Választási részvétel Lengyelországban, in: Húsz Éve Szabadon Közép-Európában, János SIMON (ed.), Budapest 2011, 165-187.

19 László BRUSZT - János SIMON, A Nagy Átalakulás, in: Politikatudományi Szemle, 1, 1992, 1, 75-98.

20 Codebook, 16.

21 lbidem, 15. 
much more protected. The elected politicians did their best to protect themselves, to save as much as possible from the former party-state nomenklatura protection and prerogatives. This meant that former politicians, government actions could not be legally answerable. They surrounded themselves with all the political constructions with bastion of laws in the new democracy on behalf of the "unequal equality". As an example, the representatives received too broad immunity rights, political issues have been for a long term encrypted, but most of the country's wealth, and the credibility of the Hungarian National Bank's gold reserves wasting - no one is held responsible. ${ }^{22}$

Hungarian Compromise of 1989 was in fact the particular transaction between the Hungarian elite, mutual recognition, strengthening the position associated with the exchange. In doing so, one side the new political elit while setting down to negotiate with the old ruling party subsequently legalized and recognized its power, which was unlawful and no legal since 1956 because of lacking free elections. In return, the old elite gave specific legitimacy and recognition to the new elite while satting down to negotiate with it, as accepted it as a power partner. Transaction based on the essence of mutual benefit can be summarized as: "Democratic legality for democratic legality". ${ }^{23}$ The 1989 democratic process in general was accompanied by tumult, strikes, demonstrations, and even gunfire sometimes in most countries of Central Europe. In Hungary, the system changes took place from the late 1980s as the pact series between the party-state elite and a small group of the inaugural new political elite, which did not strengthen the relationship of the party and the masses, but the political class became more closed and coordinated by the parties. The new political elite tried relatively soon - instead of strengthening the movement - to coordinate the operation of the power applying the basic techniques, i.e. to share the use of it. The quietest system changes in the region passed off here, as it was said "even without breaking a windowpane". The Hungarian democratization was conducted by the political elite, therefore we can call it "negotiated revolution", "quiet revolution", "melancholy revolution". ${ }^{24}$ In 1990, the two-thirds laws were not accompanied by general public opinion ovation (people either did not know or did not care) because the adoption was essentially the product of the private agreement of the elite groups; no one was interested in the opinion of the people. In essence, it was the continuation of former elitist policy that the weak civilian forces of the "broken society" were unable to ask for accountability from politicians, to counteract or resist it. ${ }^{25}$

The Antall government's work was one of the greatest historic achievements on the scale of free institutionalization surrounding themselves with bastion of legal framework. Antall resolved the organization of the legal barriers for the civil society, which provided a great boost for the establishment. But the mushrooming organizations had to face the increase

22 László BOGÁR, Összeomlás - Adalékok a rendszerváltás rendszerének bukásához, in: Húsz Éve Szabadon Közép-Európában, János SIMON (ed.), Budapest 2011, 91-97; Magdolna CSATH, A rendszerváltás és az elmaradt felzárkózás, in: Húsz Éve Szabadon Közép-Európában, János Simon (ed.), Budapest 2011, 98-105.

23 BRUSZT - SIMON, 1990; BIHARY, 1991.

24 BRUSZT - SIMON, 1990; János SIMON, Hogyan definiálható a politikai kultúra?, in: A politikai kultúra színképei, Budapest 2004, 297-317; Csaba LENTNER - Gyula TÓTH - László ZÁRUG - Péter FARKAS, Kik támadják Magyarországot és miért?, Budapest 2012, 187.

25 Zoltán BíRÓ, Elhervadt forradalom, Budapest 1993, 168. 
of unemployment not yet experienced. The impoverishment increased, the big government money missing the distribution centers where the civilians were to apply and be organized slowly by the government, or rather the situation did not have solution. In the early 1990s, people still remembered the image dominated by the old experience and compared to their experience in the authoritarian system they felt that they have a better chance in a democratic system. However, from 1992-1993 the ratio of the defencelessness diminished; between 1993 to 1998, as the privatization process got under way, crowds of people wavered in their existential security. ${ }^{26}$

The Horn government consciously and in an organized form looked for the solution to refill nongovernmental organizations with money. One of the most important legal measures was allowing the personal income tax benefit of NGOs. The initiative was so successful that later it found followers internationally. ${ }^{27}$ The Horn government on the one hand treated shock therapy for crisis management (Bokros package) and at the same time implemented historically important privatization. The economic and political transformation is considered remarkable; it is believed that as a result of the radical pro-market economic reforms people hesitated and felt more and more vulnerable. The austerity measures weakened civil society, development of civic culture based on the active participation traced back in short or medium term. Masses of plants closed down, workforce was made redundant, the unemployment grew suddenly, feelings of vulnerability to market appeared while interest groups were considered weak and helpless. The process generated hard conflicts. The situation resulted in two different ways of logic: social justice was strengthened by the democratization, while privatization of state assets into the hands of the few, in turn, apparently resulted in accelerated social polarization, unjust enrichment of the few. The hostility of the government blocked against the workers' organizations, feeling that the employees' and employers' organizations could restrict it to the economic decision-making, labor organizations could not prevent legal restrictions that the government subsequently introduced, thereupon, membership of trade unions decreased dramatically.

\section{II/3. Stable elite democracy without social control (1998-2010)}

The first Orbán government did not prevent the civilians from persuing their activities, but it did not have a program which would explicitly support the civil society. National and local politicians held the civilians in rather than seeking the cooperation with them. However, the ruling party during the election campaign turned with great force towards civilians. Between 1998 and 2002 it could not be said that the Orbán government would be in a conscious, purposeful policy to strengthen the civil society, because the Hungarian political class collectively was believed to be afraid of any appearance of civil control which could reduce or could have checked the power of government. Our statement always remained generally valid for the first twenty years of democracy (see tables no. 1. and no. 2).

26 CSATH, 98-105.

27 Arkadiusz BERNAS, Sokkal több tapasztalatot szerezhetünk egymástól!, in: Civil társadalom és érdekképviselet Közép-Európában, János SIMON (ed.), Budapest 2012, 15-17. 
Table no. 1:

The relationship between some governments (G) of the organizations of the civil society (CS) Hungary (1948-2010)

\begin{tabular}{|c|c|c|c|c|}
\hline Systems & Governments & G actions & Relation of G to CS & $\begin{array}{l}\text { Decisions of G has ... } \\
\text { the CS }\end{array}$ \\
\hline \multirow{2}{*}{$\begin{array}{l}\text { Totalitarian } \\
\text { systems } \\
\text { 1948-1989 }\end{array}$} & $\begin{array}{l}\text { Rákosi era } \\
\text { 1948-1956 }\end{array}$ & $\begin{array}{l}\text { Proscription of NGOs, } \\
\text { persecution of leaders }\end{array}$ & $\begin{array}{l}\text { Took under itself, } \\
\text { dominated }\end{array}$ & Smashed \\
\hline & $\begin{array}{l}\text { Kádár era } \\
\text { 1956-1989 }\end{array}$ & $\begin{array}{l}\text { Prohibition and } \\
\text { obstruction of funda- } \\
\text { tion of organizations }\end{array}$ & $\begin{array}{l}\text { Took under itself, } \\
\text { dominated }\end{array}$ & Destroyed \\
\hline \multirow{2}{*}{$\begin{array}{l}\text { Transitions } \\
\text { 1990-1998 }\end{array}$} & $\begin{array}{l}\text { Antall government } \\
\text { Democratic transition } \\
\text { 1990-1994 }\end{array}$ & $\begin{array}{l}\text { Extension of right of } \\
\text { assembly, movement }\end{array}$ & $\begin{array}{l}\text { Liberated but transfor- } \\
\text { med politically by the } \\
\text { Parties }\end{array}$ & $\begin{array}{l}\text { Permitted the } \\
\text { construction of }\end{array}$ \\
\hline & $\begin{array}{l}\text { Horn government } \\
\text { Postcommunist } \\
\text { 1994-1998 }\end{array}$ & $\begin{array}{l}1 \% \text { tax subsidy } \\
\text { and privatization }\end{array}$ & $\begin{array}{l}\text { Liberated but transfor- } \\
\text { med politically by the } \\
\text { Parties }\end{array}$ & $\begin{array}{l}\text { Simultaneously helped } \\
\text { and hindered }\end{array}$ \\
\hline \multirow{3}{*}{$\begin{array}{l}\text { Democratic } \\
\text { systems } \\
1998-2010\end{array}$} & $\begin{array}{l}\text { Orbán government } \\
\text { Civilian } \\
\text { 1998-2002 }\end{array}$ & $\begin{array}{l}\text { Extension of the } \\
\text { right of support } \\
\text { and movement }\end{array}$ & $\begin{array}{l}\text { Supported, tolerated } \\
\text { and kept distance }\end{array}$ & Constructed \\
\hline & $\begin{array}{l}\text { Medgyessy } \\
\text { government } \\
2002-2004\end{array}$ & Selective support & $\begin{array}{l}\text { Supported, tolerated, } \\
\text { and prohibited }\end{array}$ & $\begin{array}{l}\text { Helped and hindered } \\
\text { selectively }\end{array}$ \\
\hline & $\begin{array}{l}\text { Gyurcsány-Bajnai } \\
\text { government } \\
\text { 2004-2010 }\end{array}$ & $\begin{array}{l}\text { Selective support, } \\
\text { prohibited and } \\
\text { castigated. }\end{array}$ & $\begin{array}{l}\text { Attempt to transform } \\
\text { politically, prohibi- } \\
\text { ted, supported, and } \\
\text { tolerated. }\end{array}$ & $\begin{array}{l}\text { Combated against it } \\
\text { which partly activated } \\
\text { and radicalizated it. }\end{array}$ \\
\hline
\end{tabular}

Source: Own composition (S.J.).

The social-liberal governments between 2002 and 2010 after the initial tolerance were increasingly supported by selective political basis to the civilians, then the prohibition against criticism and protest organizations appeared in addition to the tolerance.

During the Medgyessy government - called the financier government - due to the distributing, plundering as well as sponzoring the so-called off-shore companies the country finacial reserves were totally exhausted. The Medgyessy government promoted the civilians in a sense, but rather selectively, on a political basis.

The first Gyurcsány government started functioning, having made selection for the campaign which was strongly supported by the political basis of Gyurcsány's close associations, boards, and foundations while his political rivals were disposed of. During the second Gyurcsány government the same rivals were administratively castigated too frequently, which activated them or even forced them to resist.

The disclosure of Öszöd speech meant the beginning of the political activation of the civilians. In my view, this policy began to write - in political terms - the renaissance of civil society. ${ }^{28}$ It is no coincidence that by this time opposition organisms and associations had 
worked out a kind of forum. Different bodies got to a common platform, joined forces against Gyurcsány, became more active politically, collected petitions, demonstrated more and more loudly. Most time of the Bajnai government was spent on preparation for the election campaign.

The Bajnai government essentially carried on the strand of the Bajnai government before but with much more economic constraint.

The resulting new-old political class has created a special "post-communist nomenclature", the "responsible's irresponsible system", a closed system in which politicians could not be controlled and eventually everyone did what they wanted. The privileges of the torn politician class were similar to much of the old nomenclature privileges. The country's deteriorating effect was evident at that time. The political class created their own self-protective legislation to avoid the prosecution. The power of the ruling politicians not only became uncontrolled but their "privatization activities" - by the violent qualities and privacy - often had the economy and the law at the grey zone levels. ${ }^{29}$ During the two decades, an increasing proportion of people felt that the system became more closed.

Table no. 2:

Changes in civil society (CS) at the time of certain governments (1948-2010)

\begin{tabular}{|c|c|c|c|c|c|}
\hline Systems & Governments & $\begin{array}{l}\text { Civil society } \\
\text { behaviour }\end{array}$ & $\begin{array}{l}\text { Civil society } \\
\text { Condition }\end{array}$ & $\begin{array}{l}\text { Civil society } \\
\text { Network }\end{array}$ & $\begin{array}{l}\text { Civil society } \\
\text { Nature }\end{array}$ \\
\hline \multirow{2}{*}{$\begin{array}{l}\text { Dictator- } \\
\text { ships }\end{array}$} & Rákosi era & Efforts for survival & Fearing & Fallen apart & $\begin{array}{l}\text { Mutilated civil } \\
\text { society }\end{array}$ \\
\hline & Kádár era & Enduring pursuit & $\begin{array}{l}\text { Defensive civil } \\
\text { society }\end{array}$ & $\begin{array}{l}\text { 'Era of the } \\
\text { fragmented, } \\
\text { disorganized } \\
\text { circle' }\end{array}$ & $\begin{array}{l}\text { Mutilated civil } \\
\text { society }\end{array}$ \\
\hline \multirow{2}{*}{$\begin{array}{l}\text { Transitions } \\
1990-1998\end{array}$} & $\begin{array}{l}\text { Antall government } \\
\text { Democratic } \\
\text { transition } \\
\text { 1990-1994 }\end{array}$ & $\begin{array}{l}\text { Cautious steps, } \\
\text { civil society } \\
\text { strengthening }\end{array}$ & $\begin{array}{l}\text { Strengthening } \\
\text { and organizational } \\
\text { growth }\end{array}$ & $\begin{array}{l}\text { Increasing } \\
\text { horizontal }\end{array}$ & $\begin{array}{l}\text { Regenerating } \\
\text { civil society } \\
\text { and party-related }\end{array}$ \\
\hline & $\begin{array}{l}\text { Horn government } \\
\text { Post-Communist } \\
\text { government } \\
\text { 1994-1998 }\end{array}$ & $\begin{array}{l}\text { Wait and see } \\
\text { and organize }\end{array}$ & $\begin{array}{l}\text { Trust and distrust at } \\
\text { the same time }\end{array}$ & $\begin{array}{l}\text { Strengthening } \\
\text { of horizontal } \\
\text { and vertical } \\
\text { organizations }\end{array}$ & $\begin{array}{l}\text { Regenerating } \\
\text { civil society } \\
\text { and party-related }\end{array}$ \\
\hline
\end{tabular}




\begin{tabular}{|c|c|c|c|c|c|}
\hline Systems & Governments & $\begin{array}{l}\text { Civil society } \\
\text { behaviour }\end{array}$ & $\begin{array}{l}\text { Civil society } \\
\text { Condition }\end{array}$ & $\begin{array}{l}\text { Civil society } \\
\text { Network }\end{array}$ & $\begin{array}{l}\text { Civil society } \\
\text { Nature }\end{array}$ \\
\hline \multirow{3}{*}{$\begin{array}{l}\text { Democra- } \\
\text { cies } \\
1998-2010\end{array}$} & $\begin{array}{l}\text { Orbán government } \\
\text { Civil stabilization } \\
\text { 1998-2002 }\end{array}$ & Conspiracy & $\begin{array}{l}\text { Strengthening civil } \\
\text { society, trust and } \\
\text { distrust }\end{array}$ & $\begin{array}{l}\text { Strengthening hori- } \\
\text { zontal organizations }\end{array}$ & $\begin{array}{l}\text { Party dependent } \\
\text { and independent } \\
\text { civil society }\end{array}$ \\
\hline & \multirow{2}{*}{$\begin{array}{l}\text { Medgyessy } \\
\text { government } \\
\text { Post-Communist } \\
\text { comeback } \\
\text { 2002-2004 } \\
\text { Gyurcsány/Bajnai } \\
\text { government } \\
\text { Öszöd 2004-2010 }\end{array}$} & $\begin{array}{l}\text { Conspiracy } \\
\text { activation }\end{array}$ & Mistrust, fear, anger & $\begin{array}{l}\text { Horizontal integ- } \\
\text { ration }\end{array}$ & $\begin{array}{l}\text { Party dependent } \\
\text { and independent } \\
\text { civil society }\end{array}$ \\
\hline & & $\begin{array}{l}\text { Mobilization, resis- } \\
\text { tance: beginning of } \\
\text { the renaissance of } \\
\text { civil society }\end{array}$ & $\begin{array}{l}\text { Fear, anger, agg- } \\
\text { ression }\end{array}$ & $\begin{array}{l}\text { Integration, horizon- } \\
\text { tal collaboration }\end{array}$ & $\begin{array}{l}\text { Party dependent } \\
\text { and independent } \\
\text { civil society }\end{array}$ \\
\hline
\end{tabular}

Source: Own composition (J.S.).

According to the experience gained so far, it seems that it is not the power, the government that will see the importance of the role of civil society, but the civilians will demonstrate the power that in a well-functioning democracy civilians should always be partnered up with the current government.

In 2009 it became clear to everyone that the time had come for civil society organizations to collaborate, for advocacy activities to be coordinated and for joint activities. Together we are stronger! Thus formulated in the heads of leaders of civil organizations to 'Let's unite and organize ourselves!' The idea of civil unity's importance was already born at the end of 2008 and negotiations commenced in private flats, pubs, café meetings, discussion evenings, which ultimately led to a multi-level dialogue of the larger organizations in spring of 2009 and to the formation of a wide front against the Gyurcsány-government, the Civil Joining Forums (Civil Összefogás Fórum). The country's biggest civilian coordination, the CJF (CÖF), by spring of 2010 had brought 1200 non-governmental organization together and stated a major political activity for the relay of the socialist government. ${ }^{30}$ In 2011 and 2012, the left-oriented NGOs were formed, which themselves had the integrative power (Milla, Four (Négy) K, Hahá etc.).

\section{A culture of civil society and behavior (1948-1989)}

\section{III/1. The dictatorship's distorting attitudes}

What kinds of behavioral forms may occur in the dictatorship that can be formed into pillars which can build democracy? Three forms of behavior were highlighted, which were commonly found in the four decades of authoritarian systems:

1. the "apolitical, apathetic" attitude;

2. the "faith-blinded" attitude;

3. the "terrified" attitude.

The "apathetic, apolitical" attitude is essentially characterized by indifference and apathy; 
there is the tendency to avoid any contact with anything connected with the world of politics. People tend to protect themselves or their personal integrity as an island and rather retire into private lives. The advantage of this regime for the dictatorship is that at least it does not produce any resistance, not to tell any criticism, seditious or other, at least not publicly. The main disadvantage, on the other hand, that in itself it is a passive act, a neutrality, so it does not include the important power of "unconditional willingness to follow skill" elements.

The source of "blind faith" attitude comes from a person's inability to see any other alternative, only the one in which he/she lives. It is seen as granted and naturally given, liked and finally even fallen in love with. This seems to be the same ecstatic, frantic and in delirium crying subject as the enthusiasm for Stalin and Rákosi Mátyás in the 1950s, or for the North Korean leaders nowadays.

The "terrified" attitude also includes the "unconditional willingness to follow" elements. It is moved by the fear evoked by the terror, which is also part of every institutionalized dictatorship.

The dictatorship prefers the latter two, only a softer version can tolerate the first. However, it is so true that dictatorships do not allow the first version. We just need to remember the saying of the Rákosi era: "Who is not with us, is against us!", as compared to that of the late Kádár era's: "Whoever is not against us, is for us!" meaning a dissolution.

The question nowadays is from which trust the main pillar of democracy can grow out: from the quiet survivorship or the "unconditional willingness to follow" skills? The answer can not be based on empirical data but on probabilities based on subjective experience containing a lot of uncertainty. It is supposed that some of the "apolitical" part will be activated because in the realm of freedom our own identity and integrity can be retained, even doing politics. In democracy, the fear created by the power should end. The "fearful" essentially faces the similar dilemma. Its fear of political changes and transformation may persist for a long time, but there is no place for fear in an ideal position for a stable democracy. The "fearful" do not have to dread, it have the choice whether to do politics or not, whether to be active or not. If it fed up with decades of forced politics, it will definitely move out for a while not interfering in politics, or even voting, but if one of the parties is able to awake some interest (e.g. with an attractive view or goal), it can start some sort of trust-building process in the world of politics. Yet, the reverse is also true so if there is no proper party supply, no power which can attract people to the politics or its actors, they remain mistrustful. In this case, freedom is not the freedom of choice but finally of no voting at all. The by-the-"faith-blinded"-followed monopolistic system en bloc terminates (the party, the leader and the theory altogether), and people suddenly see alternatives before them. If they can interpret them and manifests affinity towards one or another, then they will be the ones who have a strong party-bonding again in the future, or will be looking for a great leader they can trust. Most likely they will preserve electoral activity and always vote, since this process is internalized compulsorily. Only a minority retires from politics bereft of illusions, as voters. Numbers and proportions would be irresponsible to say.

At the mass level, these are the pillars that the new democracy's governments inherited from the old system and on which they are supposed to be based after the system was changed: plastic and very unpredictable. 


\section{III/2. Hiding Reviews}

The dictatorship made it, with the prohibition of the press and assembly freedom, impossible for the civil forces to establish organizations, to form political parties and interest groups, to pursue political affiliations on other than the formal channels, plus each kind of advocacy or protest actions. With the absence of free public sphere the political fragmentation of the civil society "stays hidden" ("covert public opinion"). Besides that, during more than four decades of dictatorship, the public opinion researches about the policy sphere were banned, though occasionally other kinds of researches managed to sneak into a public issue. We cannot forget to mention the respondents' fears which were strong all the time, because, due to decades of prohibitions, many were afraid to express their opinion in the eighties. The contemporary questionnaire responses included many uncertainties, "no answers" or "do-not-knows", or the respondents agreed on what the system expected them to do. These factors should be taken into account when research data are analyzed during the dictatorship.

The research of values, conducted by Hankiss Elemér and others in 1977, offered the following conclusions: those who were satisfied with their lives thought that their own success and happiness could be attributed to their own personalities, but saw that the cause of unhappy people's failure were rather the surrounding external conditions and the barriers of the social environment. ${ }^{31}$ According to the life-world researches led by Guy Lázár and László Bruszt in 1985, the Hungarians had a more satisfied self-image than people living in other countries. They felt that among all the countries of the communist region, "they live in the best", that "the equality of people" is the greatest, and that "they have the most saying in public affairs", so compared to the circumstances their place of residence is the happiest. $^{32}$

In Central Europe, in Hungary the first specifically multi-party political public opinion research was made in spring 1989 led by the writer of these lines alongside with his colleague László Bruszt. The research was repeated every or every other year between 1989 and 2010. The results thus provided 12 national surveys, set in chronological order, which were edited into a Codebook. ${ }^{33}$ Can we reply to the basic question of how the civil society itself changed, and how the people lived through the process of regime change, especially in the context of democratization and the privatization process? What do the first empirical studies details tell us about the civil society on the border of the two periods?

\section{III/3. Evaluation of the eras}

People built up their future expectations on the basis of past experience and correlated the present to this image. The new political elite had to ensure that not the past, but the present should be the starting point for the people, and to take the example from the neighbouring former state-socialist countries who also started to build economy and de-

31 Elemér HANKISS, Értékek és társadalom. Szociológiai esszék, Budapest 1977; Judit PATAKI - Edit S. MOLNÁR, Gondolkodási sémák az elégedetlenségröl, in: Jelkép, 7, 1987, 1, $29-46$.

32 BRUSZT - SIMON, 1990.

33 Codebook. 
mocracy from the scratch. In our questionnaire of spring 1989 we asked people's opinions concerning the political periods of the past 100 years on when they believed they lived best. If we look at the eras hallmarked with the names of Horthy, Rákosi and Kádár and if we look at today's democracies we can see that the vast majority of people considers the Kádár-era's performance to be the best concerning the living standard, even after two decades after the regime changes. While our democratic era constantly struggling with the economic crisis devalued, the interwar period, the Horthy-era got appreciated and in 2010 appeared on the second place. In the first place it is not saying that the (Gyurcsány, Bajnai) government knowingly advertised the appreciation of the Horthy regime, but the bad government performances lead to such a result themselves. (see table no. 3).

Table no. 3:

The change in the perception of the $20^{\text {th }}$ century eras

(from the worst - best; average 1-5; 1989-2010)

Question: "According to you when did people live under the best circumstances?"

\begin{tabular}{|c|c|c|c|}
\hline & 1989 & 2001 & 2010 \\
\hline $\begin{array}{l}\text { 1. In the Kádár era } \\
(1956-1989)\end{array}$ & $\begin{array}{l}3.9721 \\
(0.9926)\end{array}$ & $\begin{array}{l}\mathbf{4 . 0 7 4 9} \\
(1.0019)\end{array}$ & $\begin{array}{l}\mathbf{3 . 6 2 7 9} \\
(1.1484)\end{array}$ \\
\hline $\begin{array}{l}\text { 2. Horthy era } \\
\text { (1920-1944) }\end{array}$ & $\begin{array}{l}2.0321 \\
(1.0813)\end{array}$ & $\begin{array}{l}2.3322 \\
(1.2091)\end{array}$ & $\begin{array}{l}3.0427 \\
(1.3045)\end{array}$ \\
\hline $\begin{array}{l}\text { 3. Today's democracies } \\
(1989-2010)\end{array}$ & $\begin{array}{l}3.3312 \\
(1.0378)\end{array}$ & $\begin{array}{l}3.3940 \\
(1.1658)\end{array}$ & $\begin{array}{l}\mathbf{2 . 7 8 7 0} \\
(1.3601)\end{array}$ \\
\hline $\begin{array}{l}\text { 4. Rákosi era } \\
(1948-56)\end{array}$ & $\begin{array}{l}1.8914 \\
(0.9637)\end{array}$ & $\begin{array}{l}1.8630 \\
(1.0309)\end{array}$ & $\begin{array}{l}1.8106 \\
(1.0508)\end{array}$ \\
\hline
\end{tabular}

The majority is of the the opinion that "the freedom was missing" in the Kádár era (70\%) and "the suppression was big" (61\%), but "the Hungarian economy grew" (59\%) and "almost every Hungarian lived a better life" (63\%). ${ }^{34}$

\section{III/4. Distance between the civil society and politics}

The answers to the questions indicate, that people who had lived through the changes thought that with the growth of the democratic framework between 1990 and 1999 the distance between politics and citizens was not reduced, in contrary, in many aspects it increased. The fears and sustenances were maintained at relatively high levels: in $199041 \%$, in $199440 \%$ agreed that "It is better if people do not do politics because sooner or later it comes off badly". ${ }^{35}$ 
At the beginning of the change of regime and also in 1999, $80 \%$ of them said that "politicans can never be trusted" and the same $80 \%$ said that "only those in trouble are interested in politicians' opinions". ${ }^{36}$ At the same time the number of people who definitely saw a bigger distance between themselves and politics increased at the end of the nineties, compared to the beginning of the decade. Between 1990 and 1999 the rate of people who thought that "in Hungary everyone has a word in the country's cases" sunk from $43 \%$ to $31 \%{ }^{37}$, while the number of those who said that "in Hungary only those who want to make a carrier do politics" increased from $45 \%$ to $64 \% .{ }^{38}$ The rate of those who said that "the politicans do everything to learn the people's opinion" sunk from $36 \%$ to $26 \%{ }^{39}$ The parties did not bring the politics any closer, their perception depraved in the last two decades. In 2010 only $75 \%$ of respondents said that "it is important to have parties in the democracy", 10 years earlier it was the opinion of 94\%. In 1989 the majority of respondents thought that they could have a chance to take part in politics through the political parties but the number sunk to half in 2010 (46\%). ${ }^{40}$

At the same time, the number of respondents who believed that the parties served only the interests of their leaders was steadily increasing. In 2010, the proportion was $61 \%$. The only positive development to mention concerning democracy is the change in viewing the differences between the parties: while in 1990, 55\% of respondents said that they do not see any difference between the parties, twenty years later the same was said by only $22 \%$.

\section{The New Democracy's performance (1990-2010)}

We are publishing survey research data based on time-series data of two decades between 1990 and 2010 from which instructive conclusions can be drawn. Foremost is the fact that political and economic changes that took place in the world of impulses sent to the society went in many ways against the principles of the democratization and expected effects. Democracy was institutionally established but unfortunatelly the doors of institutions allowed access only to a few, they were constantly closed to the common people.

In the political culture of the masses (attitudes, orientations, values and behavior) developing the data analysis, we came to five major conclusions. The first concerns value system. Citizens' expectations are looked at in the four areas in particular which include: 1. Values and the state (government) demand for high social engagement; 2 . Corruption and closed nature of the system; 3 . The sense of vulnerability; 4 . The problem of trust-building. Let us examine these in a greater detail below.

\section{IV/1. Unvaried value system and paternalism and job search}

Somewhat surprising in relation to the people's values was the relation to no significant

\footnotetext{
36 Ibidem, 16.

37 Ibidem, 17.

38 Ibidem, 17.

39 Ibidem, 18.

40 Ibidem, 38.
} 
change in two decades, which reinforces the idea that socialization mechanisms evolve within a longer period and are more difficult to change than many people realize. Analysing the importance of 12 values it is inevitable that for the people the most important are the values of life world (peace, security, work, welfare) and the direction of public index values (forming unions, political participation) are the least important. In the Kádár era a high proportion of claimants in the state prefered a strong social role of paternalism which was explained by missing alternatives. However, the breakdown of public property and strenghtening the private one did not bring individual responsibility strengthening, the indicators showed no change. When people were asked if they should provide for themselves or whether the government should do everything to protect people from economic hardship, in $1991,76 \%$ respondents said that it was the government's duty to protect the people, in 2001 79\% thought the same, and in 2010 74\% was of the same opinion. ${ }^{41} 10$ years later after the system-changing the need for government involvement was not reduced: e.g. in 1990 and $1999,97 \%$ of respondents said that the government was supposed to take care of patients of health services. ${ }^{42}$

The work has always been a central issue for the Hungarian life world. The question aroused that the reduction of inflation or reduction of unemployment is more important task of the government. In 1990, just the minorities (45\%) chose the reduction of unemployment, in 1999 it was already $55 \%$ and in 2010 83\%. ${ }^{43}$ This also indicates that the risk of unemployment is increasing and increasing. The question how difficult it was to find another job when you lose one was answered as follows: in 1990 a little more than a half of the respondents $(53 \%)$ thought that it was not difficult or not very difficult to find a job, but the proportion raised to $64 \% \mathrm{n}$ the twenty year's time. ${ }^{44}$

\section{IV/2. Corruption, setbacks of emergency and closing the system}

Starting at $33 \%$ in 1990 , rising to $64 \%$ in 2001 , and yet at $77 \%$ in 2010 , the respondents claimed that the corruption and favoritism during the current government (Bajnai government) increased. The labor market showed growing tension in 1990; the society was still divided as for which from the two bad they would rather avoid: decrease the inflation or the unemployment rate (in propotion 55-45\%). In 1999, already 55\% of respondents said the latter, in 2010 it was $83 \% .^{45}$

In 2010, $81 \%$ of respondents said that they were "(very; rather) proud of my country". ${ }^{46}$ Despite that, during the twenty years the proportion of those who did not feel secure in their country (Hungary) increased. In comparison, those who lived in a Western country were more likely to return (in 1989 55\%, in 1999 66\%, in 2010 76\%). Another situation appeared with those who declared to choose Hungary as their country if they had to (in 1990

\footnotetext{
41 Ibidem, 33.

42 Ibidem, 34.

43 Ibidem, 35.

44 lbidem, 115.

45 Ibidem, 23.

46 lbidem, 22.
} 
$72 \%$, in 1999 55\%, in 2010 35\%)..$^{47}$

As a result, the proportion of those who feel that they are excluded increased. On this basis, the majority of people in the process of democratization do not live to see that the system becomes more open, as most participants in the democratic transition - but rather so that by the end of the process the system became dramaticly closed and excluded. In 1989, less than half citizens (46\%) was interested in what was happening in the country, in 2001 it was 75\%, and in 2010 (at the time of the Bajnai government) $87 \% .{ }^{48}$ We experience that after the two-decade-long conversion (privatization and political pluralisation), the society in general did not become more open (or more democratic), on the contrary more closed, elitist, which increased the exclusion of people. The most important background variable of this situation is the weak government performance of the political class (see table no. 4).

Table no. 4: Feeling of the system become closer $(1989-2010$ in \%)

\begin{tabular}{|l|l|l|l|l|l|l|l|l|l|}
\hline & $\mathbf{1 9 8 9}$ & $\mathbf{1 9 9 0}$ & $\mathbf{1 9 9 1}$ & $\mathbf{1 9 9 2}$ & $\mathbf{1 9 9 3}$ & $\mathbf{1 9 9 9}$ & $\mathbf{2 0 0 1}$ & $\mathbf{2 0 0 2}$ & $\mathbf{2 0 1 0}$ \\
\hline $\begin{array}{l}\text { On behalf of } \\
\text { some people }\end{array}$ & 46 & 56 & 57 & 70 & 69 & 57 & 75 & 76 & 87 \\
\hline $\begin{array}{l}\text { On behalf of } \\
\text { everybody }\end{array}$ & 54 & 44 & 43 & 30 & 31 & 43 & 25 & 24 & 13 \\
\hline $\mathrm{N}=$ & 898 & 710 & 965 & 1183 & 1135 & 986 & 1367 & 1410 & 980 \\
\hline
\end{tabular}

Source: Codebook, 31-32.

\section{IV/3. Feeling of defencelessness}

One of the most astonishing results of the survey in the post-communist countries in the early 1990s was how helpless and vulnerable the people felt on a large scale. The proportion of those who feel that they can do something against their interest-insulting at national level was altogether between $5 \%$ and $18 \%$. Comparing these Hungarian indicators with other regions, these are higher ones than Central and Eastern European datas, they close to the level of "third world" countries and far below the average of 40-70\% "stable democracies". According to the available datas - based on 11 national surveys from 1985 to 2010 - the proportion of people who feel themselves helpless and defencelessness on the national level was always above $80 \%$, even comparing the years 1990 and 2010 it is slightly increased (from $82 \%$ to $84 \%$ ). ${ }^{49}$

47 Ibidem, 22.

48 Ibidem, 31-32.

49 Ibidem, 28-29. 


\section{IV/4. Confidence, mistrust}

Confidence does not evolve in dictatorships; if there is something like confidence it must have happened by pure chance as the established dictatorship does not require trust, it can not base its roots on nuthing but absolute loyalty. Trust-building was one of the tasks of democratization processes in which the two decades showed no significant success. In Hungary, in international comparison, interpersonal trust, or confidence, the confidence within families and kinship relationships, followed by faith in God, confidence in colleagues, neighbors and fellow countrymen played substantial parts. (see table).

Pillars of democratic institution received the lowest level of trust, which explains the fact that people were not able to identify with the formal organizations permanently because those were not solid, changed the law and its forms and mechanisms too often; furthermore, privatization and debt crisis made employment unstable. The most stable unit had always been the family, which played a prominent role by socialization in the country, however in $20^{\text {th }}$ century the political ideoligies preferred by the power and their institutions have rapidly devalued. Serious reservations in institutions and a high degree of mistrust do not promote the participation of citizens in public life.

Question: "How much do you trust the following?"

Table 5: Variation of the strength of confidence

(The index 1-5, according to the 2010 sequence)

\begin{tabular}{|l|l|l|l|}
\hline \multirow{2}{*}{} & \multicolumn{2}{|c|}{ Average } & Variation \\
\cline { 2 - 4 } & $\mathbf{1 9 9 3}$ & $\mathbf{2 0 1 0}$ & $\mathbf{1 9 9 3 - 2 0 1 0}$ \\
\hline 1.Selves & 3.5414 & 3.6697 & 0.1283 \\
\hline 2.Family, relatives & 3.8258 & 3.5597 & -0.2661 \\
\hline 3.God & 2.7935 & 2.8372 & 0.0437 \\
\hline 4.Collaborator & 2.9851 & 2.6548 & -0.3303 \\
\hline 5.Employer & 2.8422 & 2.5122 & -0.3300 \\
\hline 6.Military & 2.6780 & 2.4600 & -0.2180 \\
\hline 7.Neighbours & 2.9107 & 2.4426 & -0.4681 \\
\hline 8.Fellow countrymen & 2.7004 & 2.3313 & -0.3691 \\
\hline 9.Church & 2.2504 & 2.2443 & -0.0061 \\
\hline 10.Police & 2.5747 & 2.0824 & -0.4923 \\
\hline 11.Trade unions & 2.0142 & 1.9790 & -0.0352 \\
\hline 12.Political parties & 1.8734 & 1.9246 & 0.0512 \\
\hline 13.Parliament & 2.1270 & 1.8801 & -0.2469 \\
\hline 14.Media & 2.3565 & 1.6437 & -0.7128 \\
\hline 15.Government & 2.2410 & 1.5250 & -0.7160 \\
\hline
\end{tabular}




\section{Some conclusions}

In our study we analyzed the political culture of civil society based on the historical changes and grounded our conclusions on mass-made survey data. The character of civil society and its political behaviour was described at the time of historic change.

Performance of democracy generally creates dissatisfaction, particularly in different government jobs. Less and less people feel that through the political parties they can have a chance to take part in politics; moreover, they experience that the parties become more closed, elitist and oligarchical and class-forming. Still, dissatisfaction with democracy does not mean that people aspire to dictatorship, rather a real and profound change in government and government-system, which strengthens the democracy after a long period of post-communist era. They want a "better" democracy.

The main issue drawn from the data from 2010 describes the following conclusions: after 20 years the most important values are peace, security, prosperity and employment. High expectations towards the government concerning social ineraction continued, the people were much more likely afraid of the unemployment, the percentage of those who believed that corruption and favoritism grew significantly increased. The 20 years of democracy still lacked independence, while the interpersonal trust remained relatively deep. The confidence in the democratic institutions (the parliament, political parties, trade unions, the government, media), on the contrary, kept at a low rate.

The decades of democratic development was a major breakthrough in terms of civic values. The changes are obvious, but a few civic values are weak, especially those relating to the institutions and organizations (trust, importance, activity programs). The civil society's deformation under dictatorship and its shaping during two decades of democracy did not result in a linear low-intensity civil society..$^{50}$ We have similar components as traditional peasant culture and the church described by Almond and Powell. These types of political culture are rarely found in western industrial societies, but more so in the Central-European modern agriculture-based societies, such as the Polish, Slovak, Croatian, Bulgarian. The church culture is an ideal place to set up the traditional, post-feudal society where there are no specific roles and people are not well aware of the political system. ${ }^{51}$ In Hungary and the post-communist countries, the equality and the principle of social justice changed in the time of Great Transformation several times and fluently against the logic of privatization and democratization even though the latter was the winner of a minority, yet a loser with the majority. That is why that becoming a citizen of the citizens will be a longer process, that is the way that the words of Almond lead from the "subject" political culture of citizens to the "participal" political culture of citizens. ${ }^{52}$

50 János SIMON, Mass Political Culture and Political Participation in Hungary, in: A 50 Anos de la Cultúra Civica - En Honor al Profesor Sidney Verba, Julia I. FLORES (ed.), Mexico 2011, 233-282.

51 János SIMON, Politika értékválságban - A demokratikus politikai kultúra keresése, Budapest 2013, 240.

52 Ferenc MISZLIVETZ - Jody JENSEN, Expanding Horizons. The Concept of Civil Society before and after 1989, in: Central European Political Science Review, 9, 2008, 33, 29-65; Laura MORALES DIEZ DE ULZURRUN, Ever Less Engaged Citizens? Political Participation and Associational Membership in Spain, Barcelona 2003; Leonardo MORLINO, Democracy between Consolidation and Crisis: Parties, Groups, and Citizens in Southern Europe, Oxford 1998. 
The Hungarian culture's social approach has carried a message since decades, even centuries, which concerns the "Platonic inclinations" of the Hungarians. Thus, the term of democracy is often promoted as an ideal in many ways and yet very distant from the realized (or-not-implemented) practice, which the politics distorts, reduces to its content and drowns, bares it to the material welfare and empties it of its political dimension, which leaves it action-oriented.

Overall, in the last twenty years, the Hungarian civil society texture has definitely refined, it has become more and more widespread, but emotionally it has remained at a low intensity level. The transformation took place in an irregular manner, irregular waves. Intensifying mixed with weakening, increase with waste, the interferences making the evolution difficult. This kind of development made a higher level type of development and a stronger intensity of civil society more difficult. Instead, there was a two decades long protected process, which produced a more vulnerable civil society. The leaders in civilian life often hesitated and became unsure because of the shrinking opportunities. That's why they themselves built obstacles unwittingly, so the action-space did not increase due to the low intensity often to be strengthened by themselves. It seems that the current state of political culture of Hungarian civil society is far from the participative civil culture model of Almond-Verba. The way from the paternalistic civil society to participative one takes a longer time in Hungary.

\section{Abstract}

In the study we analyzed the pillar-building process of democratic political culture on a mass level. In the first part we described the history of "broken" ("mangled") civil society during the authoritarian regimes (1949-1989). Then we analyzed the "reconstruction" of civil society in the new democracy (1990-2010). In the second part we analyzed our time series surveys (1989 to 2010). We documented a low level of political participation and social trust in politics, and low interest in the involvement in politics. The main findings support the view that the reconstruction process of civil society occurred through irregular, cyclic changes in which strengthening mixed with weakening. The changes led to a formation of civil society of greater extensity, but relatively low intensity. The further development of civic culture in Hungary will require more time.

\section{Keywords}

Political culture, citizen's behavior, voting preference, political participation, electoral campaign, well-fare state, authoritarian system, democracy, civil society

\section{References}

ALMOND, Gabriel A. - VERBA, Sidney: The Civic Culture. Political Attitudes and Democracy in Five Nations, Princeton 1963.

ÁGH, Attila: A civil társadalom kialakulása és fejlődése, Budapest 1989.

BARNES, Samuel H. - KAASE, Max: Political Action: Mass Participation in Five Western 
Democracies, Beverly Hills 1979.

BARNES, Samuel H. - SIMON, János (eds.): Postcommunist Citizen, Budapest - Washington 1999 (2nd edition).

BERÉNYI, Zoltán: Behind the Facade: weak civic culture in Hungary, in: Central European Political Science Review, 7, 2006, 26, 112-136.

BERNAS, Arkadiusz: Sokkal több tapasztalatot szerezhetünk egymástól!, in: Civil társadalom és érdekképviselet Közép-Európában, SIMON, János (ed.), Budapest 2012, 15-17.

BIHARI, Mihály: Rendszerváltás és hatalomváltás Magyarországon 1989-1990, in: Magyarország politikai évkönyve, KURTÁN, Sándor - SÁNDOR, Péter - VASS, Lázsló (eds.), Budapest 1991, 32-47.

BIHARI, Mihály - POKOL, Béla: Politológia, Budapest 2009.

BÍRÓ, Zoltán: Elhervadt forradalom, Budapest 1993.

BOGÁR, László: Összeomlás - Adalékok a rendszerváltás rendszerének bukásához, in: Húsz Éve Szabadon Közép-Európában, SIMON, János (ed.), Budapest 2011, 91-97.

BRUSZT, László - SIMON, János: Lecsendesített többség, Budapest 1990.

BRUSZT, László - SIMON, János: A Nagy Átalakulás, in: Politikatudományi Szemle, 1, 1992, 1, 75-98.

BUCHANAN, Mark: Nexus - A hálózatok úttörő tudománya, Budapest 2013.

CASTILLO, Pilar del - CRESPO, Ismael (eds.): Cultura política. Enfoques teóricos y análisis, Valencia 1997.

CSATH, Magdolna: A rendszerváltás és az elmaradt felzárkózás, in: Húsz Éve Szabadon Közép-Európában, SIMON, János (ed.), Budapest 2011, 98-105.

CZESNIK, Mikolaj: Választási részvétel Lengyelországban, in: Húsz Éve Szabadon Közép-Európában, SIMON, János (ed.), Budapest 2011, 165-187.

FERGE, Zsuzsa: Vágányok és vakvágányok a társadalompolitikában, Budapest 2012.

HANKISS, Elemér: Értékek és társadalom. Szociológiai esszék, Budapest 1977.

KOPP, Mária - SKRABSKI, Árpád: Az életminőség dimenziói - a magyar népesség az ezredfordulón, Komárom 2007, URL: www.behsci.sote.hu/kopp-skrabsky-selye-centenarium-eloadas.htm (visited: February 2013).

LENTNER, Csaba - TÓTH, Gyula - ZÁRUG, László - FARKAS, Péter: Kik támadják Magyarországot és miért?, Budapest 2012.

LOMNICl, Zoltán: Why Did Hungary Need a to Adopt a New Constitution?, in: Central European Political Science Review, 12, 2012, 43, 49-58.

MISZLIVETZ, Ferenc - JENSEN, Jody: Expanding Horizons. The Concept of Civil Society before and after 1989, in: Central European Political Science Review, 9, 2008, 33, 29-65.

MORALES DIEZ DE ULZURRUN, Laura: Ever Less Engaged Citizens? Political Participation and Associational Membership in Spain, Barcelona 2003.

MORLINO, Leonardo: Democracy between Consolidation and Crisis: Parties, Groups, and Citizens in Southern Europe, Oxford 1998.

MURAKÖZY, László (ed.): A bizalmatlanság hálójában. A magyar beteg, Budapest 2012.

PATAKI, Judit - MOLNÁR, Edit S.: Gondolkodási sémák az elégedetlenségről, in: Jelkép,

7, 1987, 1, 29-46.

POZSGAY, Imre: Politikuspálya a pártállamban és a rendszerváltásban, Budapest 1993.

PYE, Lucien: Political Culture, in: International Encyclopedia of the Social Science, Vol. 12, 
SILLS, David L. (ed.), New York 1961, 218-224.

RUPNIK, Jacques: Politikai kultúra, in: Politikai kultúra és állam Magyarországon és Cseh-Szlovákiában, GYURGYÁK, János - HALMAI, Gábor (eds.), Torino, Budapest 1991, $11-17$.

SCHMITTER, Philippe C.: The Quality of Neo-Democracy in Central Europe, in: Central European Political Science Review, 3, 2002, 9, 25-42.

SIMON, János: A politikai kultúra fogalma, in: A politikatudomány arcai, GERGELY, András A. - BAYER, József - KULCSÁR, Kálmán (eds.), Budapest 1999, 347-364.

SIMON, János: Hogyan definiálható a politikai kultúra?, in: A politikai kultúra színképei, Budapest 2004, 297-317.

SIMON, János: Civilek a demokráciáért - CÖF (Civilian for Democracy), Budapest 2010.

SIMON, János: Mass Political Culture and Political Participation in Hungary, in: A 50 Anos de la Cultúra Civica - En Honor al Profesor Sidney Verba, FLORES, Julia I. (ed.), Mexico 2011, 233-282.

SIMON, János: The Main Pillars of Democratic Political Culture in Hungary, in: Central European Political Science Review, 13, 2012, 50, 9-64.

SIMON, János: Értékválság a politikában - A demokratikus politikai kultúra keresése, Budapest 2012.

SIMON, János: A demokratikus politikai kultúra pillére Magyarországon - avagy közvélemény a magyar demokrácia 20 évéről. Codebook, Budapest-Józsefváros 2013.

SIMON, János: Politika értékválságban - A demokratikus politikai kultúra keresése, Budapest 2013.

SZABÓ, Máté: Dissent and Opposition in the Kadar-regime, in: Central European Political Science Review, 7, 2006, 26, 136-156.

VARGA, Csaba: On the Nature of Law in Communism, in: Central European Political Science Review, 12, 2011, 43, 19-48, URL: http://papers.ssrn.com/sol3/papers.cfm? abstract_id=2388420. 